\title{
Gastric Acid-Dependent Diseases: A Twentieth-Century Revolution
}

\author{
George Sachs • Jai Moo Shin $\cdot$ Keith Munson • \\ David R. Scott
}

Published online: 23 May 2014

(C) Springer Science+Business Media New York (Outside the USA) 2014

\section{Introduction}

Until recently, peptic ulcer disease (PUD) has been a major scourge to humanity, associated with high incidence of morbidity and mortality, the latter due primarily to foregut perforation or hemorrhage. Advancements in the understanding of the pathophysiology and treatment of PUD have included the discovery of gastric $\mathrm{HCl}$ secretion by Prout [1], and the realization that PUD only occurred in the presence of gastric acid [2], leading to the pronouncement "no acid, no ulcer." Apart from a strict bland diet [3], only surgery, ranging from partial or total gastrectomy to vagotomy and to selective or highly selective vagotomy successfully reduced gastric acid secretion $[4,5]$. In the last quarter of the twentieth century, three major advances took place, completely altering the treatment of gastric acidrelated diseases: (1) the development of histamine ${ }_{2}$ receptor antagonists $\left(\mathrm{H}_{2} \mathrm{RA}\right)$ as a result of rational drug design; (2) the development of proton pump inhibitors (PPIs), in part serendipitous but also followed by rational drug

\section{G. Sachs $(\bowtie)$}

Department of Medicine, David Geffen School of Medicine, The Veterans Administration Greater Los Angeles Healthcare System, University of California at Los Angeles, Bldg 113, Rm 32411301 Wilshire Blvd., Los Angeles, CA 90073, USA

e-mail: gsachs@ucla.edu

G. Sachs · K. Munson - D. R. Scott

Department of Physiology, David Geffen School of Medicine,

The Veterans Administration Greater Los Angeles Healthcare

System, University of California at Los Angeles, Los Angeles,

CA 90073, USA

J. M. Shin

Jai Scientific, Chatsworth, CA, USA design; and (3) recognition that infection by Helicobacter pylori $(\mathrm{Hp})$ is a major causative factor in peptic ulcer disease and even of gastric cancer [6,7]. In the last two decades, PUD has been replaced by gastro-esophageal reflux disease (GERD) as the major reason for physician consultation due to foregut-related symptoms.

\section{The Regulation of Acid Secretion}

Although gastric acid secretion was discovered in the 1700 s, its regulation has only been deduced relatively recently. At the time of the introduction of $\mathrm{H}_{2} \mathrm{RAs}$, gastrin, discovered by Edkins [8] and isolated by Gregory and Tracy, was thought by many to be the major direct stimulant of acid secretion [9]. Nevertheless, the first-generation $\mathrm{H}_{2} \mathrm{RAs}$, cimetidine or burimamide completely inhibited gastrin-stimulated acid secretion in rats [10], indicating that the major secretory action of gastrin was mediated by histamine. Subsequent characterization of the enterochromaffin-like (ECL) cell revealed that gastrinstimulated histamine release from this master regulator of acid secretion since gastrin stimulation of acid secretion by isolated rabbit gastric glands was completely inhibited by $\mathrm{H}_{2}$ RAs with a $1 \mathrm{nM}$ affinity [11]. Therefore, the lower affinity $(10 \mathrm{nM})$ gastrin receptor expressed in parietal cells is likely involved with trophic effects such as regulation of differentiation or growth rather than with stimulation of acid secretion. ECL cells are also stimulated by pituitary adenylate cyclase-activating peptide (PACAP) but not by acetylcholine, the vagal mediator of acid secretion, which depends on its binding to muscarinic receptor subtype 3 on parietal cells [12]. Pathways regulating parietal cell acid secretion are shown in Fig. 1. Current knowledge substantiates the central role of histamine as a stimulant of 
Fig. 1 Regulation of gastric acid secretion showing both activating and inhibitory pathways, neural, endocrine, and paracrine

\section{Regulatory Pathways of Acid Secretion}

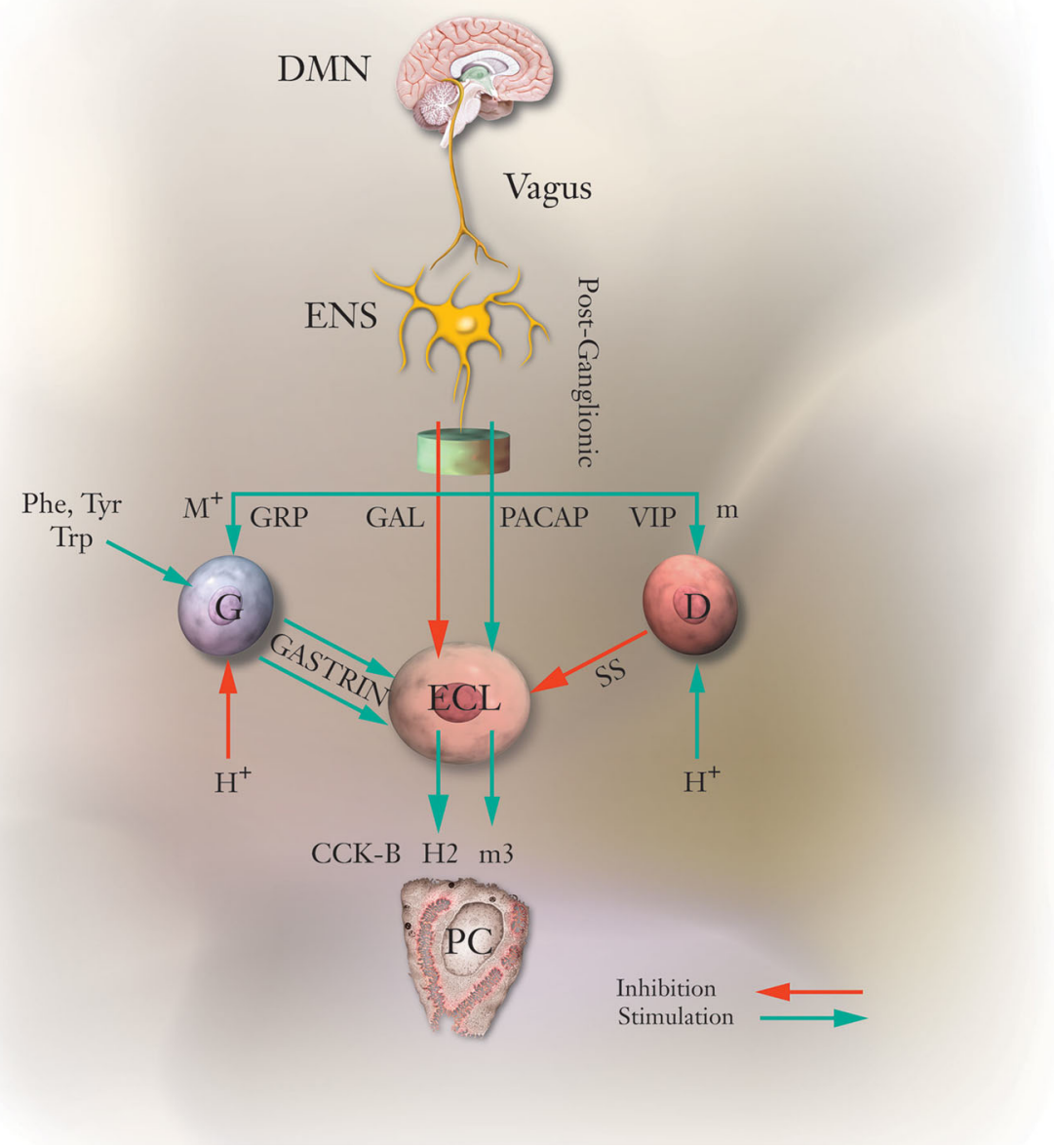

gastric acid secretion, paving the way for the discovery of $\mathrm{H}_{2} \mathrm{RA}$ as a means of down regulating secretion.

Histamine and Histamine Receptor Antagonists

Of the four histamine receptor subtypes, $\mathrm{H}_{1}$ through $\mathrm{H}_{4}$, the first of these to be targeted was the $\mathrm{H}_{1}$ receptor which is responsible for rhinitis and other allergic syndromes. The first successful small ligand receptor antagonist class ever developed was the $\mathrm{H}_{1}$ RA [13] based on the structure of histamine, a known pro-inflammatory ligand and also involved in mucus secretion [14]. Histamine is derived from decarboxylation of histidine, which yields the imidazole ethylamine, known as histamine. Early histamine ${ }_{1}$ receptor antagonists depended on the modification of the imidazole ring with retention of the ethylamine side chain. Figure 2 depicts the structure of histamine and an early $\mathrm{H}_{1} \mathrm{RA}$ pyrilamine. The $3 \mathrm{D}$ structure of the $\mathrm{H}_{1}$ receptor is now available resolved at $3.1 \AA$ resolution docked with doxepin, an early $\mathrm{H}_{1} \mathrm{RA}$ that has many unwanted effects such as drowsiness, dry mouth, and arrhythmia. A major<smiles>COc1ccc(CN(CCN(C)C)c2ccccn2)cc1</smiles>

Fig. 2 The structure of histamine and an early $\mathrm{H}_{1}$ antagonist

site of interaction is the anionic residue asp107 hydrogen bonding with the amine of the ligand (Fig. 3). Secondgeneration $\mathrm{H}_{1} \mathrm{RA}$ add a carboxylate to their structure, facilitating interaction with the lys179 amine, increasing specificity. Other $\mathrm{H}_{1} \mathrm{RA}$ also interact with lys191 further improving their selectivity [15], with a marked reduction in adverse effects. 


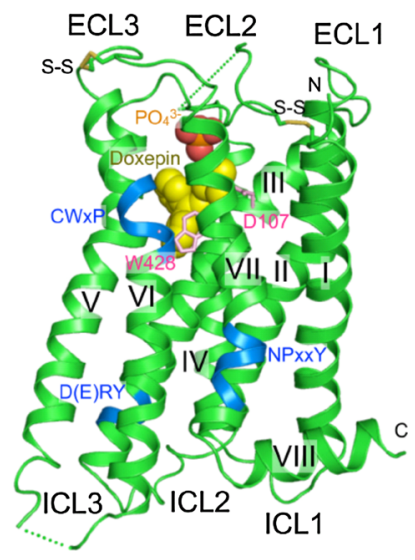

Fig. 3 The 3D structure of the $\mathrm{H}_{1}$ receptor with doxepin docked, showing interaction with Asp107 $\mathrm{H}^{+}$bonding with the amine group of the antagonist

Ash and Schild clearly differentiated the histamine receptors expressed in the circulatory system from those expressed in stomach or uterus [16] concluding that there were at least two classes of histamine receptors. James Black moved from Imperial Chemical Industries (ICI) where he had developed the first $\beta$-adrenergic inhibitor, propranolol, to Smith Kline \& French (SK\&F) in Welwyn (a stately home used during World War II to test miniature submarines since there was a very deep pond on the premises) recruited by Bill Duncan also from Glasgow. Black et al. realized that the secret to developing $\mathrm{H}_{2} \mathrm{RAs}$ was not to modify the imidazole ring of histamine as had been done for the $\mathrm{H}_{1} \mathrm{RA}$, but to modify the side chain. I was privileged, as the gastrointestinal consultant for SK\&F in Philadelphia, to be sent to Welwyn to review Jimmy Black's progress. Within a seven-year project cycle, 6 years had passed for the $\mathrm{H}_{2}$ receptor project without success! I was most impressed with the team including

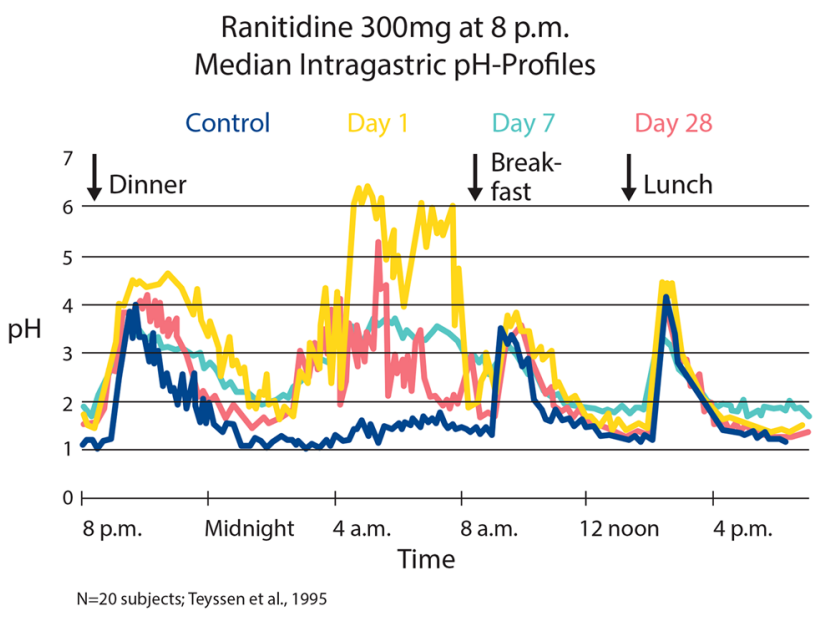

Fig. 5 The effect of once a day, evening administration of ranitidine on intragastric $\mathrm{pH}$ showing good night time effect on day 1 with $50 \%$ loss of effect by day 7 through day 28 and little effect during the day requiring BID dosing for more effective control of acid secretion compared to the four times per day recommended for cimetidine. Reprinted with permission from Macmillan Publishers Ltd: Modlin and Sachs [60]

Mike Parsons, Robin Ganellin and Graham Durant and submitted a positive report to Peter Ridley and Bryce Douglas the then head of research at SK\&F, a Glaswegian like Jimmy. A crucial tool developed by Mike Parsons was the measurement of acid secretion in the rat rather than measuring the degree of ulceration. The next year, since I was aware of the $\mathrm{H}_{2}$ antagonistic action of burimamide, I was able inhibit histamine-stimulated adenylate cyclase and submit an even more positive report [17], which eventuated in the introduction of cimetidine (Tagamet ${ }^{\circledR}$ ) as the first anti-secretory medication indicated for the treatment of peptic ulcer disease [10, 18] (Fig. 4). Cimetidine was rapidly followed by the second-generation $\mathrm{H}_{2} \mathrm{RAs}$ ranitidine, famotidine and nizatidine with somewhat different structures and differing duration of action, of which
Fig. 4 The structure of cimetidine and two other $\mathrm{H}_{2}$ antagonists. Reprinted with permission from Macmillan Publishers Ltd: Modlin and Sachs [60]

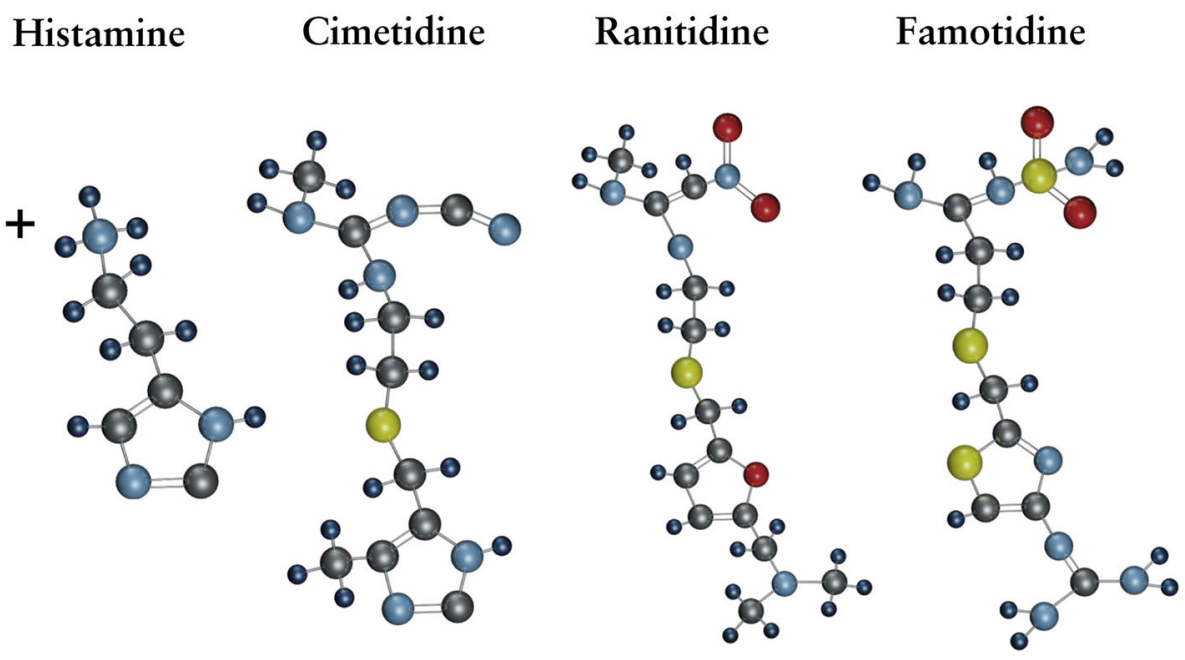


the most effective is famotidine [19]. The discovery of $\mathrm{H}_{2} \mathrm{RAs}$ not only revolutionized therapy of acid-related diseases, but also vastly improved the understanding of the control of acid secretion, as discussed above.

As experience increased with the use of $\mathrm{H}_{2} \mathrm{RAs}$, certain drawbacks to their use became apparent. Firstly, their action was short lived, requiring multiple daily doses. Secondly, all patients exhibited tolerance whereby after one week of treatment, the response was reduced by $\sim 50 \%$ [20] (Fig. 5). Hence, although relatively effective at accelerating the healing rate of duodenal ulcer, they were less effective in the treatment of gastric ulcers. Furthermore, the response in patients suffering from gastroesophageal reflux disease (GERD) was mostly inadequate [21]. A different means of inhibition of acid secretion was required. Fortunately, by that time, the gastric $\mathrm{H}^{+}, \mathrm{K}^{+}$ ATPase, the final step of acid secretion that cannot be bypassed, had been discovered. Ganser and Forte showed the presence of a $\mathrm{K}^{+}$-stimulated ATPase in frog gastric microsomes [22] and Peter Scholes working in Peter Mitchell's laboratory showed that dog microsomes alkalinized the medium in the presence of $\mathrm{K}^{+}$in the medium upon addition of MgATP [23].

Reprising our discovery of a $\mathrm{K}^{+}$-stimulated ATPase in hog gastric vesicles in 1968, we demonstrated details of the $\mathrm{H}^{+}$for $\mathrm{K}^{+}$ATPase reaction mechanism showing conclusively that it was an electroneutral $\mathrm{H}^{+}$for $\mathrm{K}^{+}$exchange $\mathrm{P}_{2^{-}}$ type ATPase lacking a $\mathrm{K}^{+}$conductance in resting enzyme [24]. This conclusion was based on the lack of effect of lipid permeable ions on either ATP-dependent $\mathrm{H}^{+}$or $\mathrm{Rb}^{+}$ transport and the absence of changes in a membrane potential sensitive dye during $\mathrm{H}^{+}$for $\mathrm{K}^{+}$exchange in the absence of the $\mathrm{K}^{+}$ionophore, valinomycin (24). A later paper used membrane potential dyes such as diethyloxadicarbocyanine or oxonol dyes to confirm electroneutrality [25].

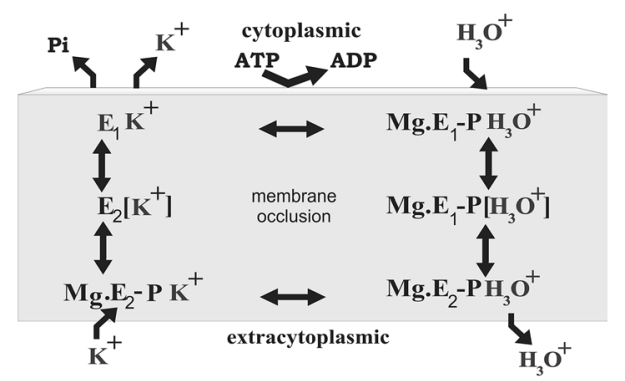

Fig. 6 The catalytic cycle of the gastric $\mathrm{H}^{+}, \mathrm{K}^{+}$ATPase. Binding of ATP and hydronium ion results in phosphorylation of the alpha subunit to result in the $\mathrm{E}_{1}-\mathrm{P}$ form which then occludes the ion and spontaneously converts to the $\mathrm{E}_{2}-\mathrm{P}$ form, releasing hydronium ion to the lumen. $\mathrm{K}^{+}$then binds resulting in dephosphorylation and formation of the $\mathrm{K}^{+}$occluded form which then releases $\mathrm{K}^{+}$to the cytoplasm reforming $\mathrm{E}_{1}$

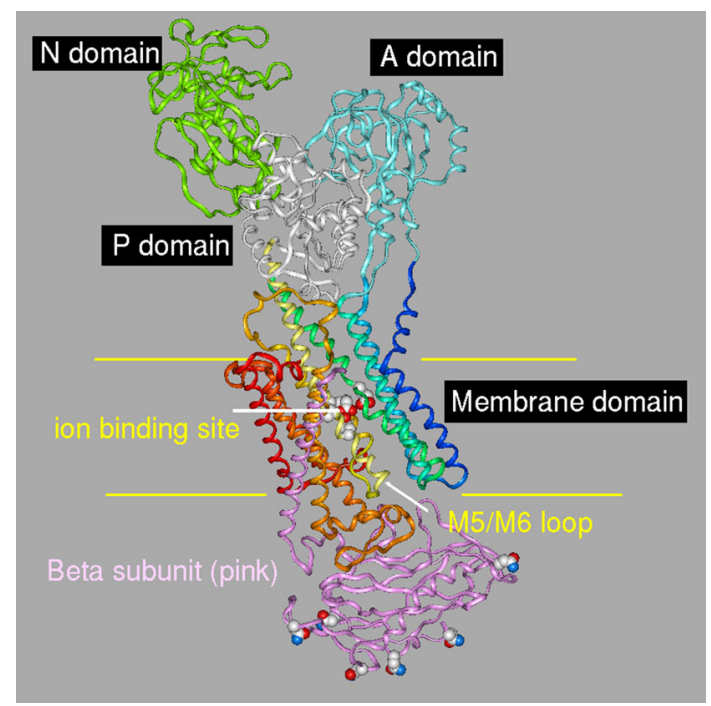

Fig. 7 A homology model of the arrangement of the two subunits of the gastric $\mathrm{H}, \mathrm{K}$ ATPase in the $\mathrm{E} 2$ form where the $\mathrm{N}$ and A domains have moved inward to the $\mathrm{P}$ domain opening a luminal vestibule allowing $\mathrm{K}$ and inhibitor access. The ion binding and glycosylation sites of the beta subunit are also shown

Mechanism of Acid Secretion: The Gastric $\mathrm{H}^{+}, \mathrm{K}^{+}$ ATPase

$\mathrm{HCl}$ secretion by the gastric parietal cell depends on activation of the gastric $\mathrm{H}^{+}, \mathrm{K}^{+}$ATPase, termed the proton pump. This enzyme is found uniquely in gastric parietal cells and in renal collecting ducts. It is an electroneutral $\mathrm{H}^{+}$ for $\mathrm{K}^{+}$exchange $\mathrm{P}_{2}$-type (phosphorylating) ATPase with ten membrane-spanning segments and a $\beta$ subunit with one transmembrane segment and six or seven glycosylation sites. The catalytic cycle is shown in Fig. 6.

At neutral $\mathrm{pH}, 2 \mathrm{H}^{+}$are exchanged for $2 \mathrm{~K}^{+}$per hydrolysis of 1 ATP, but as the luminal $\mathrm{pH}$ falls, the exchange stoichiometry is $1 \mathrm{H}^{+}$per $1 \mathrm{~K}^{+}$per 1 ATP. This stoichiometry change is explained by the $\mathrm{pK}_{\mathrm{a}}$ of one of the hydronium binding sites which remains protonated at luminal $\mathrm{pH}<3.0$ [26]. Structurally, it is a heterodimer of an $\alpha$ and $\beta$ subunit like the $\mathrm{Na}^{+}, \mathrm{K}^{+}$ATPase which may exist as a dimeric oligomer, i.e., $\alpha 2 \beta 2$ as indicated by stoichiometry of labeling with inhibitors or phosphorylation [27].

Although its 3D structure has not been solved, that of two homologous pumps has been $[27,28]$; providing valuable clues about the structure of the $\mathrm{H}^{+}, \mathrm{K}^{+}$ATPase by homology modeling, providing in turn a plausible explanation for the mechanism of acid inhibition by PPIs. The cytoplasmic domain has three loops, the $\mathrm{N}$ or nucleotide binding domain, the $\mathrm{A}$ or activation domain, and $\mathrm{P}$ the phosphorylation domain (Fig. 7). The key to transport of $\mathrm{H}^{+}$from the cytosol and absorption of $\mathrm{K}^{+}$from the lumen are conformational changes induced by phosphorylation of Asp386 by MgATP, which 


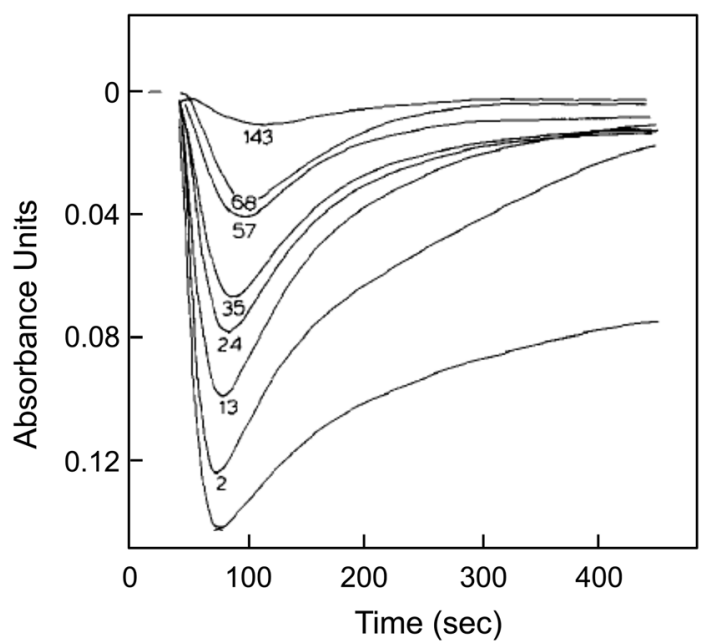

Fig. 8 The effect of ATP addition on acid transport (down curve) after different incubation times with a PPI showing delayed inhibition (up curve) The progressive effect of time of incubation at $\mathrm{pH} 7$ to activate the PPI (picoprazole)

changes the direction of net ion flux from cytoplasm $\rightarrow$ lumen to lumen $\rightarrow$ cytoplasm due to conformational changes in the cytoplasmic domain wherein the $\mathrm{N}$ and $\mathrm{A}$ domains move close to the $\mathrm{P}$ domain with closure of the cytoplasmic access pathway. There is then a spontaneous opening of a luminal vestibule allowing ion access from the luminal side. The $\mathrm{E}_{2}$ form is illustrated in Fig. 7, showing the placement of the $\beta$ subunit and six glycosylation sites. The $\beta$ subunit of the sodium pump has only three glycosylation sites which has likely impeded efforts to crystallize the protein.

\section{Activation of the Pump}

In the resting parietal cell, most of the ATPase is sequestered in cytoplasmic tubulovesicles, and upon stimulation,

Fig. 9 The pathway to the generation of omeprazole based on inhibition of gastric acid secretion and stabilization to medium $\mathrm{pH}$. Reprinted with permission from Macmillan Publishers Ltd: Modlin and Sachs [60]

it is trafficked to the apical microvilli of the secretory canaliculus [28]. Along with the pump, there is trafficking of the $\mathrm{K}^{+}$channel complex KCNQ1 and KCNE2 as well as $\mathrm{a} \mathrm{Cl}^{-}$channel. The channel trafficking is distinct from the trafficking of the ATPase [29, 30].

Proton Pump Inhibitors (PPIs)

This novel acid therapeutic class was initially discovered serendipitously by the Swedish company, AB Hässle during a secondary screen of antiviral compound candidates for anti-ulcer activity in a rat ulcer model. A compound, pyridine 2-acetamide, inhibited gastric acid secretion, even after conversion to the more stable pyridine 2-thioacetamide. Since the imidazole ring was considered essential for the anti-secretory activity of $\mathrm{H}_{2} \mathrm{RA}$, Hässle added an imidazole ring to pyridine 2-thioacetamide based on advice from their gastrointestinal consultant Lars Olbe. Since imidazole was not available, benzimidazole was added to produce pyridine 2-methylthiobenzimidazole. With an added sulfoxide to increase stability, timoprazole, the precursor of all PPIs, resulted. Since timoprazole, unlike $\mathrm{H}_{2} \mathrm{RAs}$, inhibited acid secretion independently of stimulus, it was considered a new class of antisecretory compound. My laboratory presented data showing that a polyclonal antibody against the gastric $\mathrm{H}^{+}, \mathrm{K}^{+}$ATPase reacted with extracts of the stomach, thyroid, and thymus. We therefore hypothesized that the compound inhibited the gastric $\mathrm{H}^{+}$, $\mathrm{K}^{+}$ATPase, the final step of acid secretion. Timoprazole did not inhibit purified $\mathrm{H}^{+}, \mathrm{K}^{+}$ATPase when net acid secretion was "short-circuited" by the $\mathrm{H}^{+}$for $\mathrm{K}^{+}$exchange ionophore, nigericin. Since timoprazole was acid unstable, we tested timoprazole against the $\mathrm{H}^{+}, \mathrm{K}^{+}$ATPase using conditions that promoted $\mathrm{H}^{+}$for $\mathrm{K}^{+}$exchange though the ATPase, where the compound inhibited ATP-stimulated

\section{Development of Omeprazole}

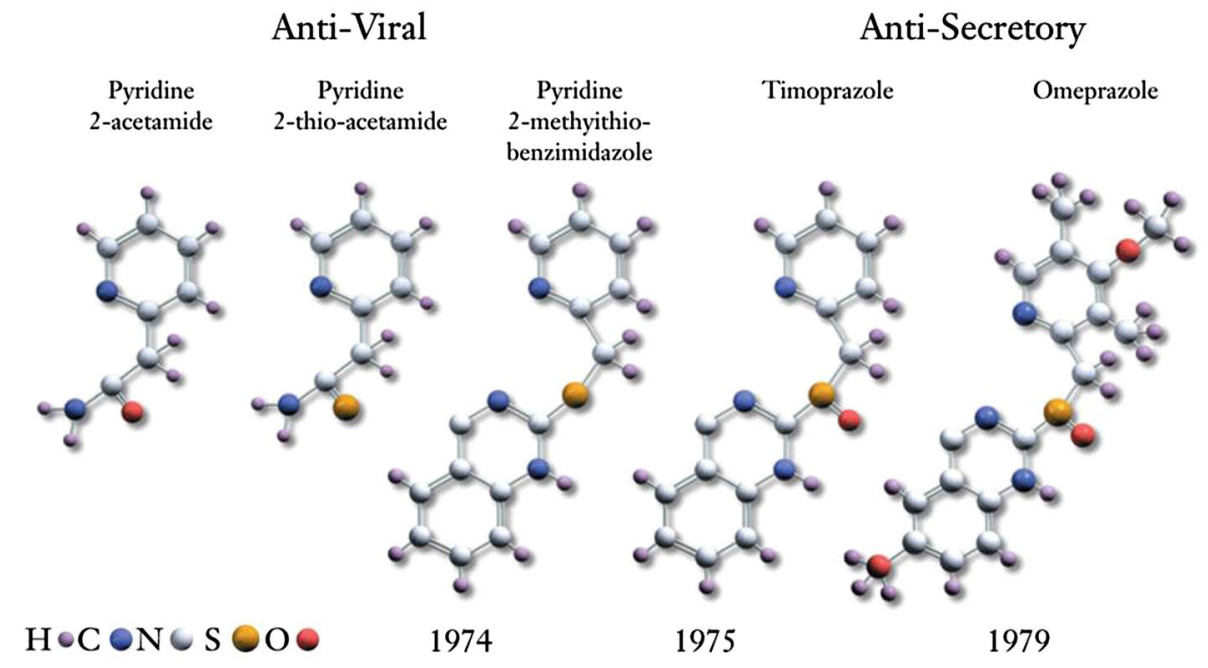

Anti-Viral

$$
\begin{array}{cc}
\text { Pyridine } & \text { Pyridine } \\
\text { 2-thio-acetamide } & \begin{array}{c}
\text { 2-methyithio- } \\
\text { benzimidazole }
\end{array}
\end{array}
$$

1974
1975
1979 
Fig. 10 The currently marketed PPIs

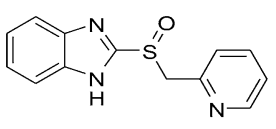

Timoprazole

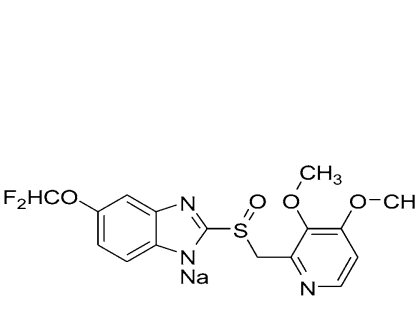

Pantoprazole

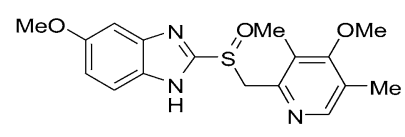

Omeprazole

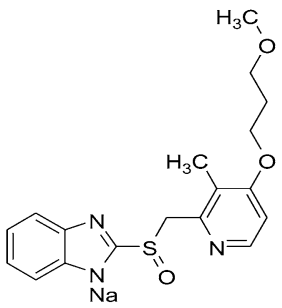

Rabeprazole

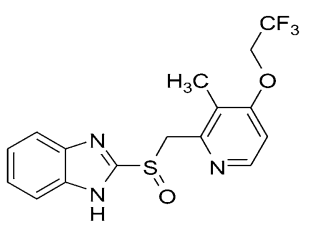

Lansoprazole

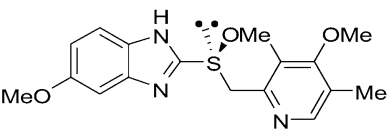

Esomeprazole
$\mathrm{H}^{+}$secretion (Fig. 8) [31]. This and experiments like this indicated that timoprazole was an acid-activated prodrug, serving as the basis for omeprazole, as shown in Fig. 9, with substitution on both the pyridine and benzimidazole rings.

Since they are acid activated, PPIs are usually enteric coated in order to impair gastric drug release. Since there is significant activation of all PPIs at neutral $\mathrm{pH}$, IV formulation of the PPIs pantoprazole and esomeprazole requires that the compound must be dissolved in buffer with $\mathrm{pH}>9.0$ in order to delay activation immediately prior to administration [32].

During the development of omeprazole, serious concerns were raised by the management of Hässle as to its value, in particular since ranitidine then dominated the antisecretory market. With my [GS] clinical background, my knowledge of its molecular mechanism and potent antisecretory properties, I was convinced that omeprazole would become the market leader in its class, with worldwide sales exceeding US \$1 billion annually, which grossly underestimated its peak sales revenue of US \$6 billion, with the overall revenue of all drugs in its class exceeding US \$20 billion annually. Every 3 months, I attended a meeting of the "PPI team" in a basement room at Hässle, which helped me maintain close collaborative ties between my laboratory and that of Hässle. The team of about 12 scientists was given total freedom by Anders Vedin, the research head at Hässle, to understand every key aspect of omeprazole and to bring it to market with no interference from oversight committees. Many of the team members spent time in my laboratory including Herbert Helander, Thomas Berglindh, Björn Wallmark, Pia Lorentzon, and Karen Gedda. Also, at the time, Byk-Gulden in Konstanz, Germany, allied with SK\&F, started PPI development, culminating in the development of pantoprazole (Protonix $\left.{ }^{\circledR}\right)$ aided by the translational studies of David Keeling and Alex Simon on loan to my laboratory. Also very important at the time was the Astra Hässle marketing manager, Ian Talmage, who was a remarkably talented in the art of product branding. All of these talented individuals have remained lifelong friends.

As phase III trials were underway, rats, but not mice or dogs, developed ECL cell carcinoid tumors, halting the clinical PPI trials, which the involved scientists were convinced was an effect of hypergastrinemia and not primarily drug dependent, supported by data generated by a Hässle team led by Enar Carlsson, which was sufficient to re-start the clinical trials. A key experiment used to support the hypergastrinemia hypothesis was that rats treated with high-dose $\mathrm{H}_{2} \mathrm{RA}$ also developed ECL tumors [33]. In contrast to rats, the ECL cell is terminally differentiated in humans, explaining why ECL tumors have not been described in humans receiving long-term, high-dose PPI therapy. Nevertheless, experimental findings prompted the competition to claim carcinogenicity for omeprazole [34].

Since the clinical introduction of omeprazole, several other drugs have entered the market which are also acidactivated prodrugs, sharing similar advantages and disadvantages with omeprazole (Fig. 10). Esomeprazole (Nexi$\left.\mathrm{um}^{\circledR}\right)$ is the S-enantiomer of omeprazole which at $40 \mathrm{mg}$ per day compared to $20 \mathrm{mg}$ per day of omeprazole shows a slight benefit in acid control. The most recent entry to the market is the D-enantiomer of lansoprazole (Dexilant ${ }^{\circledR}$ ) which is formulated be released immediately and after a $\sim$ 4-h delay. All of the PPIs in clinical use are activated prodrugs forming a thiophilic reactive group that binds covalently to one or more cysteines on the gastric $\mathrm{H}^{+}, \mathrm{K}^{+}$ ATPase irreversibly inhibiting the enzyme. 


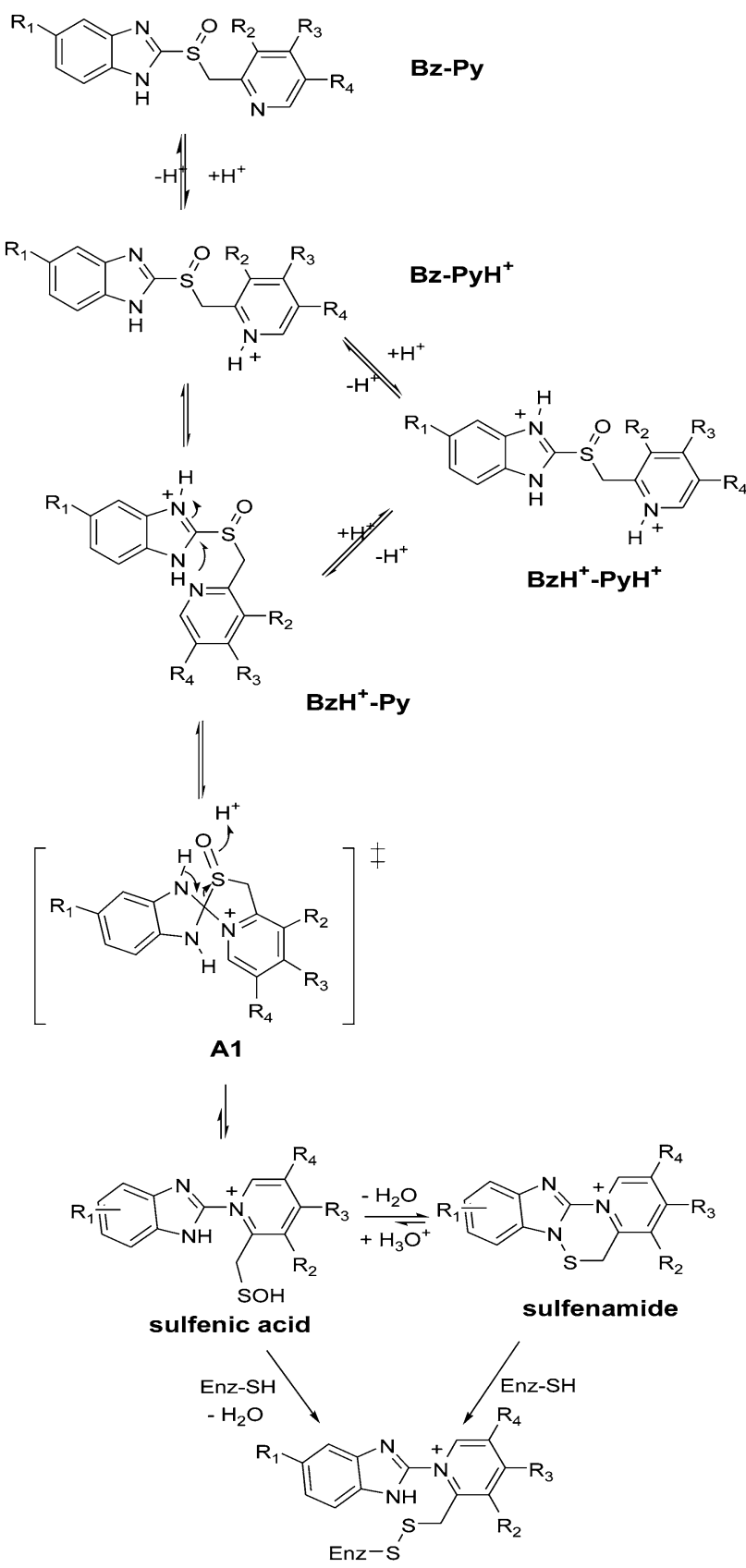

Fig. 11 The pathway of $\mathrm{pH}$ activation of a benzimidazole-based PPI. Protonation of the pyridine $\left(\mathrm{pk}_{\mathrm{a}} 4.0\right)$ allows selective accumulation of the drug in the active parietal cell and then at highly acidic $\mathrm{pH}$ of the secreting cell, protonation of the benzimidazole $\left(\mathrm{pk}_{\mathrm{a}} \sim 1-2\right)$ results in rearrangement, forming the thio-active drug

The mechanism of activation of the PPIs is a remarkable series of chemical steps as shown in Fig. 11, elucidated by Arne Brandström and Per Lindberg at Hässle and refined by Jai Moo Shin in my laboratory $[35,36]$. There is still disagreement as to whether the active compound in vivo is the sulfenic acid or the sulfenamide which was the form isolated at Hässle. Please see [37] for a comprehensive

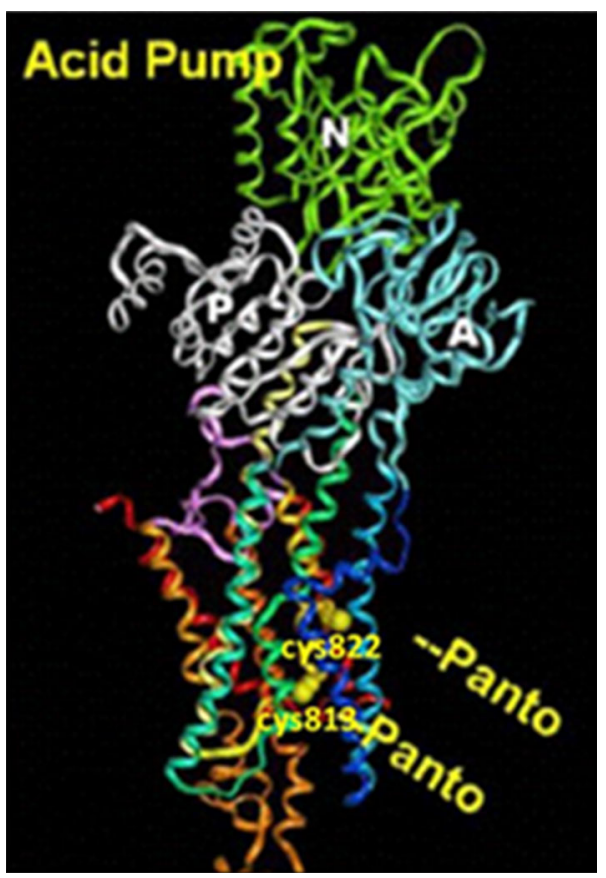

Fig. 12 The binding sites cys 813 and cys 822 of pantoprazole on the luminal face of the alpha subunit

review of this area. The mechanism is shown as a general structural form (Fig. 11). The top of Fig. 11 shows the protonation of the pyridine ring with a $\mathrm{pK}_{\mathrm{a}}$ between 4.0 (omeprazole, lansoprazole, pantoprazole) and 5.0 (rabeprazole), accumulating the protonated form only in the actively secreting parietal cell, since this is the only space with a $\mathrm{pH}<4.0$. Below that is shown the protonation of the benzimidazole ring with a $\mathrm{pK}_{\mathrm{a}}$ of $<2.0$ and in brackets is shown the mechanism of activation where the $\mathrm{C} 2$ of the protonated benzimidazole ring reacts with the unprotonated fraction of the pyridine moiety rearranging to a permanent thioreactive, cationic, tetracyclic sulfenamide that binds covalently to one or more luminally accessible cysteines of the $\alpha$ subunit of the gastric ATPase. In aqueous solution, the sulfenic acid dehydrates to form the sulfenamide. The cationic sulfenic acid or sulfenamide remains trapped in the parietal cell canaliculus. In the particular case of pantoprazole, cysteine 813 and cysteine 822 become covalently linked (Fig. 12). With other PPIs different cysteines are linked but cysteine 813 is derivatized by all PPIs and must be considered as the central target for this class of drug. It is easy to visualize that binding of a PPI covalently in this region will fix the pump in the $\mathrm{E}_{2}$ form and inhibits cycling back to the $\mathrm{E}_{1}$ form.

Thus, since PPIs require ongoing acid secretion in order to be activated, they are administered 30-60 min before breakfast so that peak blood concentrations coincide with maximal $\mathrm{H}^{+}, \mathrm{K}^{+}$ATPase activity. In spite of the need for 
Pantoprazole $40 \mathrm{mg}$ at 8 a.m.

Median Intragastric $\mathrm{pH}$-Profiles

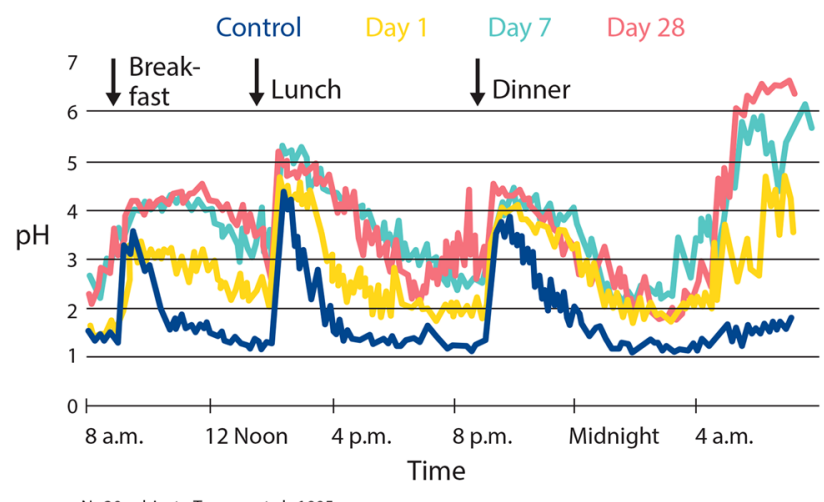

$\mathrm{N}=20$ subjects; Teyssen et al., 1995

Fig. 13 Intragastric pH profile with PPIs before breakfast. Arrow show $\mathrm{pH}$ at night $<2.0$. Reprinted with permission from Macmillan Publishers Ltd: Harder et al. [61]

careful timing with meals, $\mathrm{pH}$ suppression by PPIs is superior to that of $\mathrm{H}_{2} \mathrm{RAs}$ due to lack of tolerance. A typical intragastric $\mathrm{pH}$ profile after PPI treatment is shown in Fig. 13, with progressive improvement in acid control with daily dosing. Although significant inhibition of acid secretion is present on the first day of dosing, inhibition improves significantly up to the third or fifth day of dosing, since with covalent labeling of pumps cycling between activity and inactivity, the percentage of inhibited pumps progressively increases. With a half-life of about $50 \mathrm{~h}$, $\sim 25 \%$ of pumps are synthesized de novo synthesis/day, hence maximal pump inhibition on once daily dosing can only reach $75 \%$ of maximal acid secretion. As can be seen in the $\mathrm{pH}$ profile after multiple treatments of once-daily PPI, intragastric $\mathrm{pH}$ still falls to $<2.0$ in the middle of the night, a finding scarcely affected even with twice daily mealtime dosing, due to the short plasma half-life ( $\sim 90 \mathrm{~min}$ ) of all currently marketed PPIs with no drug present when newly synthesized or previously silent pumps become active.

\section{Marketing of Omeprazole}

Merck launched omeprazole in the United States in 1989 under the name $\operatorname{Losec}^{\circledR}$ which was changed to Prilosec ${ }^{\circledR}$ in the United States a year later in order to avoid confusion with similarly named products. The superiority of omeprazole over $\mathrm{H}_{2}$ RAs was most evident in the treatment of GERD which became, and continues to be, the major clinical indication for PPIs. As a result of a systematic meta-analysis of the correlation of intragastric $\mathrm{pH}$ and clinical outcome, maintenance of intragastric $\mathrm{pH}>3.0$ for $12 \mathrm{~h}$ /day optimized the healing of duodenal ulcer, whereas maintenance

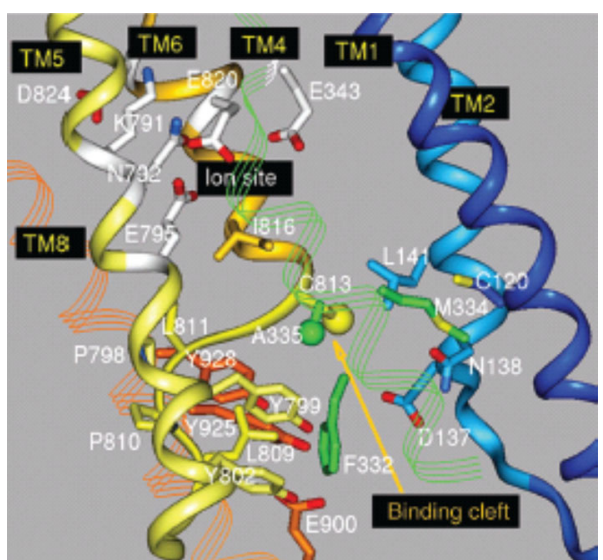

Fig. 14 Higher magnification of the luminal vestibule of the $E_{2}$ form of the alpha subunit showing access to cys 813 the common covalent binding site of all PPIs

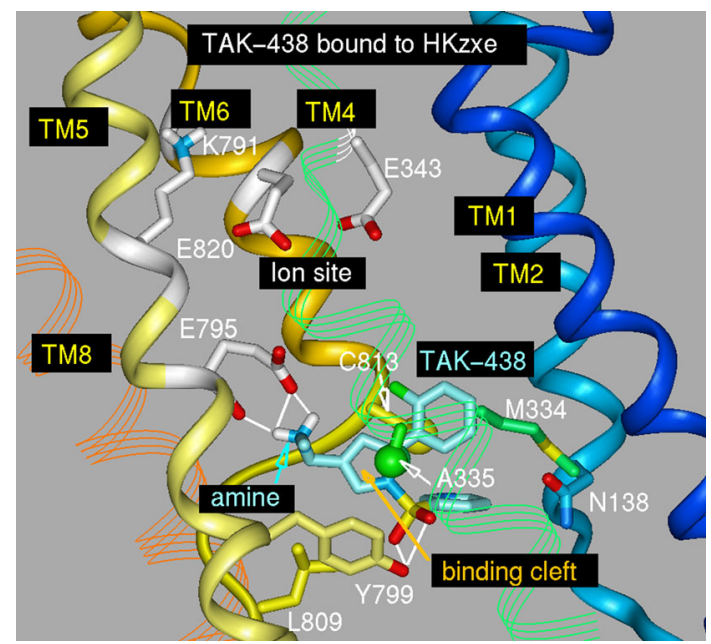

Fig. 15 The modeled binding site of the $\mathrm{K}^{+}$competitive inhibitor, TAK-438, binding in the same region as omeprazole

of $\mathrm{pH}>4.0$ for $18 \mathrm{~h} /$ day optimized the treatment of GERD $[38,39]$. At the time of launch, ranitidine had overtaken cimetidine as the major drug used for acid-related diseases largely due to its twice daily dosing compared with four times daily for cimetidine. "Scare" strategies, such as stating that omeprazole permanently inhibited acid secretion, were employed to discredit omeprazole, even though the ongoing synthesis of new pumps and clinical experience did not support this. The climax of the fight came when a letter appeared in the journal Lancet claiming that omeprazole induced unscheduled DNA synthesis (UDS) in isolated parietal cells implying that omeprazole was carcinogenic [34]. The technique used, which was developed in my 


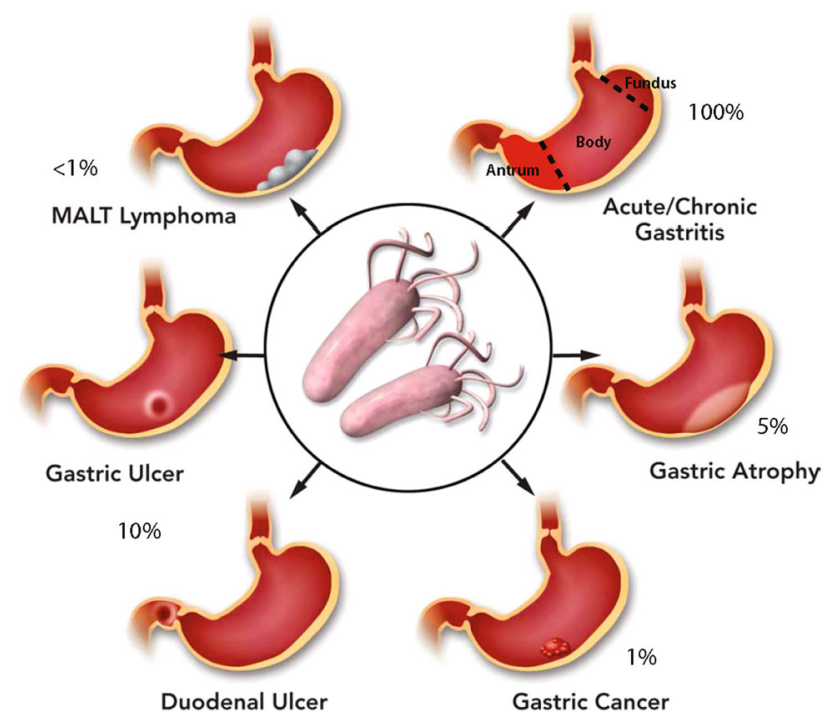

Fig. 16 The outcomes of infection by Helicobacter pylori. Reprinted with permission from Macmillan Publishers Ltd: Sachs and Scott [62]

laboratory [40, 41], did not discriminate between surface cells and oxyntic cells. Surface cells are derived from constantly dividing stem cells which continuously physiologically incorporate the DNA precursor thymidine, which is not indicative of UDS. Moreover, the Lancet article's author published half of the dose-response curve, whereas the complete curve was bell-shaped and clearly could not represent UDS. Several subsequently published studies did not support the UDS hypothesis, removing any lingering doubts regarding the superiority of PPIs over $\mathrm{H}_{2} \mathrm{RAs}$ for treatment of GERD [42].

\section{Current Situation of Clinical Use of PPIs}

The PPI class of drugs, though still the most widely used in the acid-related disease market, has been attributed with certain drawbacks over time. For example, $20 \%$ of GERD patients continue to have reflux symptoms despite maximal PPI therapy, due to the presence of poorly suppressed nocturnal acid secretion. A novel sulfonamide prodrug of omeprazole AGN904, with delayed absorption is capable of maintaining intragastric $\mathrm{pH}>5.0$ for $24 \mathrm{~h} / \mathrm{day}$, promises to be effective for the recalcitrant $20 \%$ of GERD patients with prominent nocturnal secretion [43], and also for the eradication of $\mathrm{Hp}$ which become persistent and

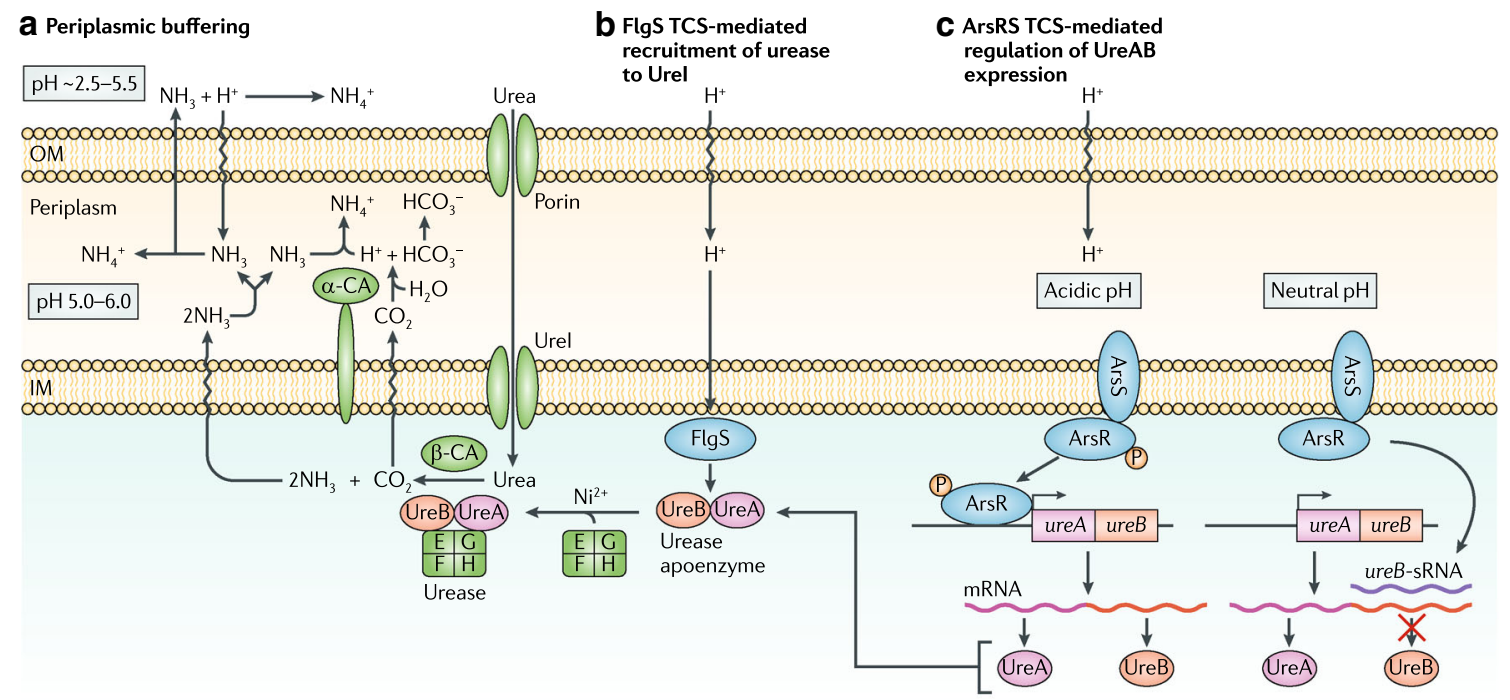

Nature Reviews | Microbiology

Fig. 17 Periplasmic buffering by Helicobacter pylori and its regulation. $a$ Urea crosses the outer membrane $(\mathrm{OM})$ and then the inner membrane (IM) through the pH-gated urea channel, UreI, at an external $\mathrm{pH}<6.0$. Cytoplasmic urease forms $2 \mathrm{NH}_{3}+\mathrm{H}_{2} \mathrm{CO}_{3}$ and the latter is converted to $\mathrm{CO}_{2}$ by cytoplasmic $\beta$-carbonic anhydrase. These gases cross the IM, and the $\mathrm{CO}_{2}$ is converted to $\mathrm{HCO}_{3}$ - by the membrane bound $\alpha$-carbonic anhydrase thus maintaining periplasmic $\mathrm{pH}$ at $\sim 6.1$, the effective $\mathrm{pK}_{\mathrm{a}}$ of the $\mathrm{CO}_{2} / \mathrm{HCO}_{3}{ }^{-}$couple. Exiting $\mathrm{NH}_{3}$ neutralizes the $\mathrm{H}^{+}$produced by carbonic anhydrase as well as entering $\mathrm{H}^{+}$and can also exit the $\mathrm{OM}$ to neutralize the medium and thus allows elevation of periplasmic $\mathrm{pH}$ to higher than medium. $b$ The role of the $\mathrm{pH}$ responsive two component system, TCS, FlgS encoded by HP0244. Activation results in recruitment of urease proteins to UreI and the immediate access of urea and outward transport of $\mathrm{CO}_{2}$, $\mathrm{NH}_{3}$ and $\mathrm{NH}_{4}^{+}$through UreI increases the rate of periplasmic buffering. $c$ A model representing the role of regulation by the TCS ArsRS (encoded by HP0165/HP0166). At neutral pH, ArsS is inactive and ArsR is not phosphorylated. This ArsR binds to the promoter of the sRNA that targets the $u r e B$ part of the ureAB mRNA (ureBsRNA) and consequent truncation of ure $A B$ mRNA with a decline in urease activity. This reflects a likely adaptation to neutral $\mathrm{pH}$. At acidic $\mathrm{pH}$, ArsS is activated with ArsR phosphorylation and this results in upregulation of $u r e A B$ mRNA and consequent increase in acid-protective urease activity 
hence untreatable at intragastric $\mathrm{pH}<3.0$ [44] contributing to the $>30 \%$ failure of standard triple therapy in acid hypersecretors. Some adverse effects of PPIs include hypocalcaemia in elderly patients undergoing chronic therapy [45]. A very small number of patients may develop hypomagnesaemia with serious effects on the central nervous, cardiac, and musculoskeletal systems [46], possibly due to a mutation in the duodenal $\mathrm{Mg}$ transporters enhancing their susceptibility to activated PPIs in the duodenum [47]. On the whole, however, given their relatively minor adverse effects discovered only after millions of patient-years of experience, and their unceasing and potent effectiveness, which has revolutionized the treatment of acid-peptic foregut disease, these drugs have a remarkably low risk/benefit.

\section{Reversible Inhibitors of the Gastric $\mathrm{H}^{+}, \mathrm{K}^{+}$ATPase}

With generation of the $\mathrm{E}_{2} \mathrm{P}$ form, a luminal vestibule is formed by changes in orientation of the transmembrane domains (illustrated in Fig. 14), emphasizing the access pathway for inhibitors such PPIs and the $\mathrm{K}^{+}$competitive inhibitors of the pump. In the early 1980s, my laboratory was exploring the role of $\mathrm{Ca}^{2+}$ in stimulus-secretion coupling in the parietal cell, testing $\mathrm{Ca}^{2+}$ channel blockers such as trifluoperazine, verapamil, and 8 - $(N, N$-diethylamino)octyl-3,4,5-trimethoxybenzoate on acid secretion in rabbit gastric glands. The $\mathrm{K}_{\mathrm{i}}$ for acid secretion is at least ten times higher than the $\mathrm{K}_{\mathrm{i}}$ for $\mathrm{Ca}^{2+}$ channel blockade, due to direct competitive inhibition of the ATPase with $\mathrm{K}^{+}$ [48]. Based on this study, we demonstrated that an experimental antisecretory drug SCH28080, originally synthesized as an omeprazole mimetic, was in fact a $\mathrm{K}^{+}$ competitive proton pump inhibitor [49]. Due to the huge PPI market, intense pharmaceutical interest has been directed at the discovery of a potent, safe, and long-lasting antisecretory drugs to compete with the PPIs, as illustrated in the Fig. 15, which eventuated in the synthesis of pyrrolo-pyridines such as TAK-438 [50, 51]. The success of this new class depends on very slow dissociation from the pump with binding to the same vestibule as omeprazole. This compound, currently under development in the Far East, if successful will have the advantage of immediate, meal independent inhibition of acid secretion and no need for enteric coating.

\section{Helicobacter Pylori}

In 1983, Warren and Marshall provided evidence that infection with $H p$ contributes substantially to duodenal ulcer recurrence [7] (Fig. 16). This discovery revolutionized the concepts of pathogenesis and the treatment of
PUD. When the relationship between $H p$ infection and gastric adenocarcinoma was found, it seemed clear that such infection should be actively treated. Nevertheless, there is still controversy as to whether the bacterium is a pathogen or a commensal [52], hence the concept of test and treat is not universally accepted [53]. The relationship of $\mathrm{Hp}$ infection to PUD and to gastric cancer created a paradigm shift in treatment of PUD [54], suggesting strongly that prophylactic eradication is justified. It is universally accepted that eradication is needed for symptomatic disease.

There are two major areas of current research, the host response and the mechanisms behind the ability of the organism to colonize the human stomach. In my laboratory, we have been mostly concerned with discovering the means whereby only $H p$ is able to colonize the normal human stomach. $\mathrm{Hp}$ is a neutralophile, meaning that it grows best at neutral $\mathrm{pH}$ and does not grow at $\mathrm{pH}<5.0$ or $>8.2$. The key property exhibited by this organism is its ability to buffer its periplasm to near neutral in acidic environments, mimicking a neutralophilic environment (Fig. 17). The transcriptome of $H p$ recovered from the gerbil stomach is consistent with a $<\mathrm{pH} 4.0$ habitat [55].

\section{Eradication of $H p$}

In the 1990s, triple therapy using two antibiotics such as amoxicillin with either clarithromycin or metronidazole and an antisecretory drug such as an $\mathrm{H}_{2} \mathrm{RA}$ or PPI was an effective means of $\mathrm{Hp}$ eradication, with $\sim 90 \%$ efficacy. In the twenty-first century, resistance to the latter two antibiotics reduced efficacy to $<70 \%$, requiring a different regimen [53]. To improve eradication rates, which is of particular importance given the billions of infected individuals worldwide, either novel antibiotic independent targets are required or a modification of antibiotic therapy is required. One novel method is to add bismuth subcitrate to the triple therapy, termed quadruple therapy, or to add other antibiotics, although these approaches only modestly improve eradication rates [56]. From the analysis of the gastric biology of the organism, several druggable targets have been discovered, such as the external facing proteins UreI, HP0165, or FrbP4 or ExbD or NixA [57, 58]. Interference with these molecular targets will require development of novel agents present in the stomach for a sufficient time to facilitate $H p$ killing.

Another approach derives from an understanding of the need for acid suppression coupled with antibiotics in eradication regimens. As noted above, at $\mathrm{pH} 3.0$ the organism ceases to grow, developing a persistent phenotype. Potent acid suppression, achieving $\mathrm{pH}>5.0,24 \mathrm{~h} /$ day, abolishes this persistence [44]. Although current PPIs fall short of this goal, the use of a more effective PPIs such 
as the prodrug of omeprazole, AGN904, or the aforementioned long-acting $\mathrm{K}^{+}$competitive inhibitor, TAK-438, may overcome this problem. Since resistance to amoxicillin is very rare, treatment with omeprazole and amoxicillin in slow omeprazole metabolizers which suppresses acid secretion to near this level resulted in excellent eradication [59], supporting this strategy. Hence, this dual therapy could successfully replace current triple therapy.

\section{Summary}

In the last quarter of the twentieth century, the treatment of PUD radically changed from the former mainstays of diet and surgery to the development of $\mathrm{H}_{2}$ receptor antagonists that were the first effective medical means of PUD treatment. Nevertheless, a relatively weak response for heartburn or gastroesophageal reflux disease and tolerance development prompted the search for more effective treatments. The discovery of the gastric $\mathrm{H}^{+}, \mathrm{K}^{+}$ ATPase, the final step of acid secretion, termed the proton pump, followed by the development of the proton pump inhibitors forever altered PUD and GERD treatment. The discovery of the causative role of infection by $H p$ now make its eradication the standard-of-care for patients with gastric symptoms. All clinically useful $H p$ eradication regimens include a PPI, presumably to reduce the persistent state of the organism in the stomach by elevating intragastric $\mathrm{pH}$. The future may lie in application of more effective means of eradication and more effective inhibitors of the gastric proton pump.

\section{References}

1. Prout W. On the nature of the acid and saline matters usually existing in stomachs of animals. Philos Trans $R$ Soc Lond. 1824;114:45-49.

2. Schwartz C. Beitrage zur Pathologie und chirugischen des penetrierenden Magenheschwüren. Mitt Grenzengeb Med Chir (Jena). 1900;5:821-848.

3. Sippy BW. Landmark article May 15, 1915: gastric and duodenal ulcer. Medical cure by an efficient removal of gastric juice corrosion. By Bertram W. Sippy. J Am Med Assoc. 1983;250:2192-2197.

4. Horsley GW, Barnes WC. Twenty-five years' experience with Billroth I gastric resection. Ann Surg. 1957;145:758-766 (discussion, 766-759).

5. McLeod RS, Cohen Z. Highly selective vagotomy and truncal vagotomy and pyloroplasty for duodenal ulcer: a clinical review. Can J Surg. 1979;22:113-120.

6. Herrera V, Parsonnet J. Helicobacter pylori and gastric adenocarcinoma. Clin Microbiol Infect Off Publ Euro Soc Clin Microbiol Infect Dis. 2009;15:971-976.

7. Marshall BJ, Warren JR. Unidentified curved bacilli in the stomach of patients with gastritis and peptic ulceration. Lancet. 1984;1:1311-1315.
8. Edkins JS. The chemical mechanism of gastric secretion. $J$ Physiol. 1906;34:133-144.

9. Gregory RA, Tracy HJ, Harris JI, et al. Minigastrin; corrected structure and synthesis. Hoppe-Seyler's Zeitschrift fur Physiologische Chemie.. 1979;360:73-80.

10. Black JW, Duncan WA, Durant CJ, Ganellin CR, Parsons EM. Definition and antagonism of histamine $\mathrm{H}$ 2-receptors. Nature. 1972;236:385-390.

11. Sachs G, Zeng N, Prinz C. Physiology of isolated gastric endocrine cells. Аnnu Rev Physiol. 1997;59:243-256.

12. Wilkes JM, Kajimura M, Scott DR, Hersey SJ, Sachs G. Muscarinic responses of gastric parietal cells. J Membr Biol. 1991;122:97-110.

13. Bovet D. Introduction to antihistamine agents and antergan derivative. Ann N Y Acad Sci. 1950;50:1089-1126.

14. Beaven MA. Histamine: its role in physiological and pathological processes. Monogr Allergy. 1978;13:1-113.

15. Shimamura T, Shiroishi M, Weyand S, et al. Structure of the human histamine H1 receptor complex with doxepin. Nature. 2011;475:65-70.

16. Ash AS, Schild HO. Receptors mediating some actions of histamine. Br J Pharmacol Chemother.. 1966;27:427-439.

17. Sung CP, Jenkins BC, Burns LR, et al. Adenyl and guanyl cyclase in rabbit gastric mucosa. Am J Physiol. 1973;225:1359-1363.

18. Brimblecombe RW, Duncan WA, Durant GJ, Ganellin CR, Parsons ME, Black JW. The pharmacology of cimetidine, a new histamine H2-receptor antagonist. Br J Pharmacol. 1975;53:435P-436P.

19. Schunack W. What are the differences between the H2-receptor antagonists? Aliment Pharmacol Ther. 1987;1:493S-503S.

20. Nwokolo CU, Prewett EJ, Sawyerr AM, Hudson M, Lim S, Pounder RE. Tolerance during 5 months of dosing with ranitidine, $150 \mathrm{mg}$ nightly: a placebo-controlled, double-blind study. Gastroenterology. 1991;101:948-953.

21. Hotz J. [Pathophysiology of esophageal motility] Zeitschrift fur Gastroenterologie. 1990;28:52-55 (discussion 70-51).

22. Ganser AL, Forte JG. $\mathrm{K}^{+}$-stimulated ATPase in purified microsomes of bullfrog oxyntic cells. Biochim Biophys Acta. 1973;307:169-180.

23. Lee J, Simpson G, Scholes P. An ATPase from dog gastric mucosa: changes of outer $\mathrm{pH}$ in suspensions of membrane vesicles accompanying ATP hydrolysis. Biochem Biophys Res Commun. 1974;60:825-832.

24. Sachs G, Chang HH, Rabon E, Schackman R, Lewin M, Saccomani G. A nonelectrogenic $\mathrm{H}+$ pump in plasma membranes of hog stomach. J Biol Chem. 1976;251:7690-7698.

25. Rabon E, Chang H, Sachs G. Quantitation of hydrogen ion and potential gradients in gastric plasma membrane vesicles. Biochemistry. 1978;17:3345-3353.

26. Rabon EC, McFall TL, Sachs G. The gastric [H, K]ATPase:H+l ATP stoichiometry. J Biol Chem. 1982;257:6296-6299.

27. Shin JM, Sachs G. Dimerization of the gastric H+, K(+)-ATPase. J Biol Chem. 1996;271:1904-1908.

28. Forte JG, Zhu L. Apical recycling of the gastric parietal cell H, K-ATPase. Ann Rev Physiol. 2010;72:273-296.

29. Lambrecht NW, Yakubov I, Scott D, Sachs G. Identification of the $\mathrm{K}$ efflux channel coupled to the gastric H-K-ATPase during acid secretion. Physiol Genomics. 2005;21:81-91.

30. Nguyen N, Kozer-Gorevich N, Gliddon BL, et al. Independent trafficking of the KCNQ1 $\mathrm{K}+$ channel and $\mathrm{H}+-\mathrm{K}+$-ATPase in gastric parietal cells from mice American journal of physiology. Gastrointest Liver Physiol. 2013;304:G157-G166.

31. Wallmark B, Sachs G, Mardh S, Fellenius E. Inhibition of gastric $(\mathrm{H}++\mathrm{K}+)$-ATPase by the substituted benzimidazole, picoprazole. Biochim Biophys Acta. 1983;728:31-38.

32. Armstrong D, Bair D, James C, Tanser L, Escobedo S, Nevin K. Oral esomeprazole vs. intravenous pantoprazole: a comparison of 
the effect on intragastric $\mathrm{pH}$ in healthy subjects. Aliment Pharmacol Ther. 2003;18:705-711.

33. Ekman L, Hansson E, Havu N, Carlsson E, Lundberg C. Toxicological studies on omeprazole. Scand J Gastroenterol Suppl. 1985;108:53-69.

34. Burlinson B, Morriss SH, Gatehouse DG, Tweats DJ. Genotoxicity studies of gastric acid inhibiting drugs. Lancet. 1990;335: 419-420.

35. Lindberg P, Nordberg P, Alminger T, Brandstrom A, Wallmark B. The mechanism of action of the gastric acid secretion inhibitor omeprazole. J Med Chem. 1986;29:1327-1329.

36. Sachs G, Shin JM, Besancon M, Prinz C. The continuing development of gastric acid pump inhibitors. Aliment Pharmacol Ther. 1993;7:4-12 (discussion 29-31).

37. Sachs G, Shin JM, Briving C, Wallmark B, Hersey S. The pharmacology of the gastric acid pump: the $\mathrm{H}+, \mathrm{K}+\mathrm{ATPase}$. Annu Rev Pharmacol Toxicol. 1995;35:277-305.

38. Burget DW, Chiverton SG, Hunt RH. Is there an optimal degree of acid suppression for healing of duodenal ulcers? A model of the relationship between ulcer healing and acid suppression. Gastroenterology. 1990;99:345-351.

39. Hunt RH. The relationship between the control of $\mathrm{pH}$ and healing and symptom relief in gastro-oesophageal reflux disease. Aliment Pharmacol Ther. 1995;9:3-7.

40. Blum AL, Shah GT, Wiebelhaus VD, et al. Pronase method for isolation of viable cells from Necturus gastric mucosa. Gastroenterology. 1971;61:189-200.

41. Scott D, Reuben M, Zampighi G, Sachs G. Cell isolation and genotoxicity assessment in gastric mucosa. Dig Dis Sci. 1990;35:1217-1225.

42. Fryklund J, Falknas AK, Helander HF. Omeprazole does not cause unscheduled DNA synthesis in rabbit parietal cells in vitro. Scand J Gastroenterol. 1992;27:521-528.

43. Hunt RH, Armstrong D, Yaghoobi M, et al. Predictable prolonged suppression of gastric acidity with a novel proton pump inhibitor, AGN 201904-Z. Aliment Pharmacol Ther. 2008;28: 187-199.

44. Marcus EA, Inatomi N, Nagami GT, Sachs G, Scott DR. The effects of varying acidity on Helicobacter pylori growth and the bactericidal efficacy of ampicillin. Aliment Pharmacol Ther. 2012;36:972-979.

45. Subbiah V, Tayek JA. Tetany secondary to the use of a protonpump inhibitor. Ann Intern Med. 2002;137:219.

46. Tamura T, Sakaeda T, Kadoyama K, Okuno Y. Omeprazole- and esomeprazole-associated hypomagnesaemia: data mining of the public version of the FDA adverse event reporting system. Int $J$ Med Sci. 2012;9:322-326.

47. Lameris AL, Hess MW, van Kruijsbergen I, Hoenderop JG, Bindels RJ. Omeprazole enhances the colonic expression of the $\mathrm{Mg}(2+)$ transporter TRPM6. Pflugers Arch. 2013;465:1613-1620.

48. Im WB, Blakeman DP, Mendlein J, Sachs G. Inhibition of $(\mathrm{H}+\mathrm{K}+)$-ATPase and $\mathrm{H}+$ accumulation in hog gastric membranes by trifluoperazine, verapamil and 8-(N,
N-diethylamino)octyl-3,4,5-trimethoxybenzoate. Biochim Biophys Acta. 1984;770:65-72.

49. Wallmark B, Briving C, Fryklund J, et al. Inhibition of gastric $\mathrm{H}+, \mathrm{K}+-\mathrm{ATPase}$ and acid secretion by $\mathrm{SCH} 28080$, a substituted pyridyl(1,2a)imidazole. J Biol Chem. 1987;262:2077-2084.

50. Hori Y, Imanishi A, Matsukawa J, et al. 1-[5-(2-Fluorophenyl)-1(pyridin-3-ylsulfonyl)-1H-pyrrol-3-yl]-N-methylmethanamin e monofumarate (TAK-438), a novel and potent potassium-competitive acid blocker for the treatment of acid-related diseases. $J$ Pharmacol Exp Ther. 2010;335:231-238.

51. Shin JM, Inatomi N, Munson K, et al. Characterization of a novel potassium-competitive acid blocker of the gastric H, K-ATPase, 1-[5-(2-fluorophenyl)-1-(pyridin-3-ylsulfonyl)-1H-pyrrol-3-yl]N-methylmethanamin e monofumarate (TAK-438). J Pharmacol Exp Ther. 2011;339:412-420.

52. Chen Y, Blaser MJ. Helicobacter pylori colonization is inversely associated with childhood asthma. J Infect Dis. 2008;198: $553-560$

53. Malfertheiner P, Megraud F, O'Morain CA et al. Management of Helicobacter pylori infection-the maastricht IV/florence consensus report. Gut. 2012;61:646-664.

54. Moss SF. The rediscovery of $H$. pylori bacteria in the gastric mucosa by Robin Warren, and implications of this finding for human biology and disease. Dig Dis Sci. 2013;58:3072-3078.

55. Scott DR, Marcus EA, Wen Y, Oh J, Sachs G. Gene expression in vivo shows that Helicobacter pylori colonizes an acidic niche on the gastric surface. Proc Natl Acad Sci USA. 2007;104: $7235-7240$.

56. Malfertheiner P, Bazzoli F, Delchier JC, et al. Helicobacter pylori eradication with a capsule containing bismuth subcitrate potassium, metronidazole, and tetracycline given with omeprazole versus clarithromycin-based triple therapy: a randomised, open-label, non-inferiority, phase 3 trial. Lancet. 2011;377: 905-913.

57. Ang S, Lee CZ, Peck K, et al. Acid-induced gene expression in Helicobacter pylori: study in genomic scale by microarray. Infect Immun. 2001;69:1679-1686.

58. Wen Y, Marcus EA, Matrubutham U, Gleeson MA, Scott DR, Sachs G. Acid-adaptive genes of Helicobacter pylori. Infect Immun. 2003;71:5921-5939.

59. Furuta T, Shirai N, Ohashi K, Ishizaki T. Therapeutic impact of CYP2C19 pharmacogenetics on proton pump inhibitor-based eradication therapy for Helicobacter pylori. Methods Find Exp Clin Pharmacol. 2003;25:131-143.

60. Modlin IM, Sachs G. Acid related diseases: biology and treatment. Lippincott: Williams and Wilkins; 2004.

61. Harder H, Teyssen S, Stephan F, et al. Effect of 7-day therapy with different doses of the proton pump inhibitor lansoprazole on the intragastric $\mathrm{pH}$ in healthy human subjects. Scand J Gastroenterol. 1999;34:551-561.

62. Sachs G, Scott DR. Helicobacter pylori: eradication or preservation. F1000 Med Rep 2012;4:7. 